\title{
The Role of Product Innovation in Mediating Market Orientation with Marketing Performance
}

\author{
Gusti Agung Ayu Widyaningsih \\ Faculty of Economics and Business \\ University of Udayana \\ Bali, Indonesia \\ gustiayuwidyaningsih@gmail.com \\ I Gusti Ayu Ketut Giantari \\ Faculty of Economics and Business \\ University of Udayana \\ Bali, Indonesia \\ Corresponding author: ayugiantari@unud.ac.id
}

\author{
Ni Nyoman Kerti Yasa \\ Faculty of Economics and Business \\ University of Udayana \\ Bali, Indonesia \\ manraikerti@yahoo.co.id \\ I G A Dewi Adnyani \\ Faculty of Economics and Business \\ University of Udayana \\ Bali, Indonesia \\ igadewi@yahoo.com
}

\begin{abstract}
The aim of this research is to explain the product innovation role in mediating relationship between market orientations with marketing performance to restaurant industry in Denpasar City. This research was conducted by the owners or manager of restaurant in Denpasar City by using questionnaire that was taken directly. The sample size that used is 112 respondents with purposive sampling method. The techniques of analysis data are path analysis and Sobel test. The result of research shows that market orientation and product innovation has significant and positive influence on the marketing performance. The practice implication which is gained from this research is it should be giving more pay attention to the market orientation for restaurant industry in Denpasar city so that it will implicate to the product innovation and give a good marketing performance.
\end{abstract}

Keywords-market orientation; product innovations; marketing performance

\section{INTRODUCTION}

The era of globalization and the implementation of MEA 2015 makes every effort around the world prosecuted more aggressively in running a business to win the competition in their respective business industries. Every business needs to further improve its performance without abandoning the quality of products offered. All business players should have acknowledged that the role of Micro Small Medium Enterprises (MSMEs) in this era of globalization is very useful to accelerate the economic development in some particular areas.

According to the Central Statistics Agency (BPS), the existence of MSMEs is grouped into medium large and small micro industries. In general, small industries are considered to be able surviving and anticipating the economics sluggishness. According to [1], Small and Medium Enterprises (SMEs) is a small business unit that can become an alternative business activity of goods and services production, as well as increasing the labor absorption.

SMEs could become a source of income for the community, and it is very potent as a trigger for economic growth. SMEs have a strategic role in national economic development, economic growth, employment and play an important role in distributing development outcomes [2]. Many restaurant industries that are widespread around Indonesia currently experiencing business growth and income increasing each year, this is because of consumers' demands and needs that are also increasing.

Along with the development of modern and fast-paced era, consumers always want to try new products, therefore, marketing performance can be an interesting issue for marketers these days. Restaurant industries according to [3] is a very large and complex business activities, including hot dog stands on the beach, the cafeteria in the office environment, food stalls, Padang restaurant, fried chicken, food stalls alongside toll roads and others.

The development of tourism in Bali makes MSMEs development is increasing, especially in Denpasar city as the capital city of Bali province. Denpasar also a center of education, government, and economics because it is more crowded than other cities in Bali.

H1: Market orientation has a positive and significant effect on product innovation

Previous research by [4] states that market orientation (customer orientation, competitor orientation, and cross- 
functional coordination) has a positive influence on product innovation in Small and Medium Industries of Pekalongan Batik. [5] state that market orientation has a positive effect on innovation in private healthcare organizations in Turkey. [6] indicate that market orientation has a positive influence on innovation in SMEs Batik Jawa Tengah. [7] stated that market orientation has a positive and significant effect on innovation of SMEs in Banyumas Regency.

H2: Market orientation has a positive and significant impact on marketing performance

Market orientation has a positive and significant impact on the performance of Endek SMEs in Klungkung Regency [8]. [9] stated that market orientation has a positive and significant influence on marketing performance of furniture and furniture industry in Semarang city. [10] found that market orientation contributed positively and significantly to business performance in beauty salon and spa service industry in Pekan Baru city. [11] found that market orientation has a positive and significant effect on marketing performance in Small-Medium Industry of Rattan Handicraft in Teluk Wetan Village, Welahan Sub-district of Jepara Regency. Meanwhile, [12] found that firm performance in the manufacturing sector in Kenya was influenced by market orientation.

H3: Product innovation has a positive and significant impact on marketing performance

According to [7] innovation has a positive influence on business performance on SMEs in Banyumas regency. [9] on his research proved that innovation has a positive and significant influence on the furniture and manufacturing industries of Semarang City. [13] showed that innovation has a positive and significant impact on SMEs Mojokerto footwear industry. [4] stated that product innovation has a positive influence on marketing performance in Small and Medium Industry of Pekalongan Batik. Innovation has a positive and significant effect on marketing performance on Small-Medium Industry of Rattan Handicraft in Teluk Wetan Village, Welahan Sub-district of Jepara Regency [11].

H4: Product innovation significantly mediates market orientation to marketing performance

Market orientation has a positive but insignificant effect on marketing performance [14]. However, market orientation has a significant effect on marketing performance through product innovation as an intervening variable. [5] stated that innovation is highly dependent on market orientation and will play the role of mediator to drive organizational performance in private healthcare organizations in Turkey.

\section{RESEARCH METHOD}

Based on the main problems, this research can be classified as associative research, i.e. research that aims to determine the relationship between two or more variables. This research was conducted in Denpasar City. The reason for choosing it as the location is because Denpasar City experiencing a very rapid economic growth than other areas in Bali, it makes the proliferations of various restaurants causing the intensity of tight competitions between restaurant industries in Denpasar City. This research subjecting on the owner or managers of restaurant industries in Denpasar City. The object of this research is the influence of market orientation on marketing performance mediated by product innovation.

Market orientation (X) as a free variable in this research, was divided into three indicators of market orientation which were adapted from [15] which is always paying attention to consumer's taste, always oriented to customer's satisfaction, give close attention to after sales service, quickly respond to competitor's threatening competitiveness, regularly discuss in company about competitor's activity, top management regularly discuss competitor strategy, keep improving service, all business functions of the company (marketing/sales) have an integrated strategy in serving customers, and all departments being responsive in serving the needs and demands of customers.

The product innovation (Y1) is the mediation variable in this research. The indicator of this variable was adopted from [16] [17] which are: always developing new products, always using new raw materials, always improving quality, and keep developing new product's packaging. The dependent variable of this research is marketing performance (Y2). The indicator of this variable was adopted from [18] [19] [20] which are: increasing of sales turnover, increasing of profit earned, and the improvement of after-sales service. This research was using qualitative data which is subject's statement during questionnaire interview, therefore this research was using primary data, which is a questionnaire and secondary data, which are books, journal theory and heirloom related to the problems.

The population of this research is the owner or manager of restaurant industries in Denpasar City. The research sample was chosen using nonprobability sampling with purposive sampling method. The sampling criteria are the owner or manager of the restaurant. This consideration is used because the owner or manager assumed to have more knowledge about running and managing the restaurants also able to relate and understand each content of the questionnaire.

By using 16 indicators, the used the 7 times larger size is needed so that the estimation based on the number of parameters can be obtained a sample size of 112 respondents. The method used in collecting the data using questionnaires was measured by using Likert Scale. This research uses Path Analysis, where [21] mentioned the steps to analyze the data using this method as follows:

\section{a) Sub-structural Equation 1}

$$
\mathrm{Y}_{2}=\beta_{1} \mathrm{X}_{1}+\mathrm{e}
$$

b) Sub-structural Equation 2

$$
\mathrm{Y}_{2}=\beta_{1} \mathrm{X}_{1}+\beta_{2} \mathrm{Y}_{1}+\mathrm{e}
$$

$\mathrm{Y}_{2}$ is switching brand, $\mathrm{X}_{1}$ is dissatisfaction, $\mathrm{Y}_{1}$ is emotional response, $\beta_{1}$ and $\beta_{2}$ are variable regression coefficients, and e is error. 


\section{ReSUlt AND Discussion}

The validity test runs on the research instruments shows that all indicators in market orientation variable, marketing performance, and product innovation have Pearson correlation greater than 0.30 so it means all the indicators have met the data validity requirements. The reliability test was used to indicate whether the measuring instruments used are reliable or not. This test is performed on the research instruments with Cronbach's Alpha coefficient, if greater than 0.60 then the instrument used in this research is reliable, and the other way around. Reliability test result of this research instruments shows that market orientation, marketing performance, and product innovation variable each has Cronbach's Alpha coefficient greater than 0.60 which means the statements on the questionnaire are reliable to use.

This research was using path analysis technique, i.e. an extension of multiple linear regression analysis to test the causality relationship between two or more variables. Based on the test results, the equation is as follows:

$$
\begin{gathered}
Y_{2}=\beta_{2} X+\beta_{3} Y_{1}+e_{2} \\
Y_{2}=0,702 X+0,167 Y_{1}+e_{2}
\end{gathered}
$$

Based on the equation, it can be concluded that:

The value of $\beta 2$ is 0.702 which means market orientation has a positive effect on product innovation. In other words, if market orientation factor increases, it will result in an increase of innovation of restaurant industries in Denpasar City by 0.702 . And the value of $\beta 3$ is 0.167 which means that the product innovation response has a positive effect on the marketing performance. In other words, if the factor of product innovation increases, it will result in an increase of marketing performance of the restaurant industries in Denpasar City by 0.167 .

Sobel test results of this research indicate that the value of $\mathrm{Z}$ is 2.1348 , this value is greater than the specified value which is 1.96 with a significance level of 0.000 . It shows that product innovation variables are able to mediate the relationship between market orientation and marketing performance. The test result shows a positive beta coefficient value of 0.693 with a significance level of 0.000 (less than $0.05)$ which means $\mathrm{H} 1$ is accepted.

This result indicates that market orientation variables have a positive and significant effect on product innovation of restaurant industries in Denpasar City through customer orientation approach, competitor orientation, and interfunctional coordination will increase product innovation of the restaurants in Denpasar City. These results are supported by [6] which stated that market orientation (customer orientation, competitor orientation, and cross-functional coordination) have a positive effect on product innovation on Small and Medium Industries of Pekalongan Batik.

Market orientation have a positive effect on innovation in private healthcare organizations in Turkey [market orientation has a significant positive effect on innovation of SMEs in Banyumas Regency [7]. [6] also indicated that market orientation has a significant positive effect on innovation of SMEs in Central Java Batik.

Further testing results show the value of the positive beta coefficient is 0.702 with a significance level of 0.000 (less than 0.05) which means $\mathrm{H} 2$ is accepted. This indicates that market orientation variables have a positive and significant effect on marketing performance of restaurant industries in Denpasar City. This also means that the better the restaurant industries understand the market through market orientation, the marketing performance in those restaurant industries will be increasing, and vice versa, the lower the understanding of market orientation, the marketing performance will certainly be decreasing.

The results of this research support the result of previous research by [11] which found that market orientation has positive and significant effects on marketing performance in Small-Medium Industries of Rattan Handicraft in Teluk Wetan Village Welahan Sub-district of Jepara Regency. [10] found that market orientation contributed positively and significantly to business performance in beauty salon and spa service industries in Pekanbaru city. Thus [22] also found that market orientation has a positive and significant impact on business performance on small-scale processing businesses in Palembang City. [23] stated that market orientation has a positive and significant effect on marketing performance of Batu Kota fruit chips. It is stated that the more SMEs in Batu City fruit chips are market-oriented, the higher the marketing performance will be.

Further test results on this research show a positive beta coefficient value of 0.167 with a 0.000 significance level (less than 0.05) which means $\mathrm{H} 3$ is accepted. This indicates that the product innovation variables on the marketing performance are accepted, it shows that product innovation has a positive and significant effect on marketing performance of restaurant industries in Denpasar City. It means, the more innovative restaurant industries in making innovation by creating new ideas, creating more attractive designs and packaging, improving the quality of the menu and flavor and actively developing the quality of their products, the more marketing performance of restaurant businesses will improve, and vice versa, the less they make innovation, the less improvement of marketing performance will they be.

The results of this study in accordance with previous research by [7] which stated that innovation has a significant positive effect on the business performance of SMEs in Banyumas District. [13] stated that innovation positively influences the marketing performance of SMEs in Mojokerto municipal footwear by continuing to innovate SMEs footwear in Mojokerto City, it will further increase its credibility in terms of product variation, thus increasing the marketing performance on sales of its products. [6] also stated that innovation has a significant positive effect on marketing performance of SMEs Batik in Central Java.

The development of new services offered has a positive and significant impact on marketing performance [13]. [2] showed that product innovation has a positive and significant effect on marketing performance of Handicraft Industries in Yogyakarta, Solo, and Bandung. [11] also stated that 
innovation has a positive and significant effect on marketing performance in Small-Medium Industry of Rattan Handicraft in Teluk Wetan Village, Welahan Sub-district of Jepara Regency.

Based on the results of hypothesis testing on product innovation mediation in the relationship between market orientation and marketing performance by using Sobel Test shows the role of emotional response significantly mediate the influence of consumer dissatisfaction on the transfer of brands which obtains $\mathrm{Z}$ value of 2.1348 where this value is greater than the determined value that is 1.96 with a significance level of 0.00000 less than 0.05 , which means $\mathrm{H} 4$ is also being accepted.

The result shows that product innovation variables are able to significantly mediate the relationship between market orientation variables to marketing performance. The results of this study are in accordance with previous research which is [26] that stated market orientation has a positive effect on marketing performance through innovation as the mediation variable on automotive manufacturing companies in Spain.

Innovation was able to mediate the relationship between market orientation and marketing performance [27]. [6] also stated that market orientation in SMEs Batik will have more significant impact on marketing performance if it is to be mediated by innovation, which means that the performance of SME marketing Batik is highly dependent on the level of corporate innovation as well as the level of market orientation which influence innovation. Innovation is highly dependent on market orientation and will play the role of mediator to drive organizational performance in private healthcare organizations in Turkey [5].

\section{CONCLUSION}

Based on the results that have been mentioned, it can be concluded that:

Market orientation has a positive and significant effect on product innovation. This means that the better the restaurant industries understand the market through customer orientation, competitor orientation, and inter-functional coordination approach, the higher the innovation of the restaurant industries in Denpasar City will be.

Market orientation has a positive and significant effect on the marketing performance, meaning that the better the restaurant industries understand the market through customer orientation, competitor orientation, and inter-functional coordination approach, the higher the performance of the restaurant industries in Denpasar City will be.

Product innovation has a positive and significant impact on marketing performance, which means the more the restaurant industries making innovation by creating new products, attractive packaging designs and actively doing product development and improving product quality, it will surely increase consumers interest to come and try and even re-buy the products offered. It will increase the marketing performance of restaurant industries in Denpasar City.
Product innovation can significantly mediate the relationship between market orientation and marketing performance. These results also indicate that if the restaurant industries in Denpasar City were into market-oriented then this attitude will be able to improve product innovation and ultimately will be able to increase marketing performance on restaurant industries in Denpasar City.

\section{Suggestion}

Based on the conclusions, it can be suggested that: Restaurant industries in Denpasar City had already implemented good market orientation, but the restaurant businesses need to pay more attention to after-sales service which must be improved to create greater value to the customers; Top management of restaurant industries should be more organized in discussing competitor oriented strategies that can be used to determine a strategy to obtain competitive advantage; Owners, managers and all functionals of restaurant businesses should have an integrated strategy in serving the customer in order to be able to maximize the potential in serving customers. With good coordination and the clarity of information, everyone responsible in the company will be able to provide integrated services in running the business to satisfy consumer needs; Restaurant industries in Denpasar City had implemented product innovation, but the businesses should pay more attention to developing new products packaging in accordance with market desires in every occasion and producing more varied products packaging; Restaurant industries in Denpasar City need to improve their marketing performance. Whether owners or managers, both should have always improved the degree of market orientation by collecting customer information, competitor information and continue making inter-functional coordination and making products innovation so it can be well accepted by customers. It will absolutely increase the demand for the product and will automatically improve the marketing performance itself.

For further research, other variables should be added, such as business environment variable, competitive advantage as the mediation variable also firm size as the moderation variable could be added. In addition, the sample and scope of research can be expanded and not limited only to Denpasar City

\section{References}

[1] Afiah. Nunuy Nur, "Peran Kewirausahaan dalam Memperkuat UKM Indonesia Menghadapi Krisis Finansial Global," Journal Accounting and finance, vol. 22 (1), 2009, pp. 1-9.

[2] Nur, Nofal., Surachman., Ubud Salim., Djumahir.. Entrepreneurship Orientation, Market Orientation, Business Strategy, Management Capabilities On Business Performance; Study At Small and Medium Enterprise Printing In kendari. International Journal of Business and Management Invention. 3(12), 2014. pp: 08-17.

[3] Atmodjo Widjojo Marsum, Restoran dan Segala Permasalahannya. Yogyakarta: Andi, 2005

[4] Suendro, Ginanjar. Analisis Pengaruh Inovasi Produk Melalui Kinerja Pemasaran Untuk Mencapai Keunggulan Bersaing Berkelanjutan (Studi kasus pada Industri Kecil dan Menengah Batik Pekalongan). Tesis Program Studi Magister Manajemen Program Pascasarjana Universitas Diponegoro, Semarang. . 2010. 
[5] Altuntaş. G, Semerciöz. F, and Eregez. H, "Linking Strategic and Market Orientations to Organizational Performance: The Role of Innovation in Private Healthcare Organizations," Procedia - Social and Behavioral Sciences, vol. 99 (9), 2013, pp. 413-419.

[6] Pardi, S., Suyadi, I. and Arifin, Z. The Effect of Market Orientation and Entrepreneurial Orientation toward Learning Orientation, Innovation, Competitive Advantages and Marketing Performance. European Journal of Business and Management, 6 (21), 2014.pp: 69-80

[7] Suliyanto and Rahab. The Role of Market Orientation and Learning Orientation in Improving Innovativeness and Performance of Small and Medium Enterprises. Asian Social Science, 8 (1), 2012.pp: 134-145.

[8] Pramesti, Ni Made Vera. I G. A. Kt. Giantari. Peran Orientasi Pasar Memediasi Pengaruh Orientasi Kewirausahaan Terhadap Kinerja UKM Industri Kerajinan Kain Endek (Studi di Kabupaten Klungkung). EJurnal Manajemen Unud, 5 (9), 2016. h: 5754-5782. ISSN : 23028912.

[9] Titahena, Alexander Daniel, Syukur Abdul, Utomo Dwiarso “Analisis Pengaruh Orientasi Pasar, Inovasi Dan Orientasi Kewirausahaan Terhadap Kinerja Pemasaran Dengan Intervening Keunggulan Bersaing”, Jurnal Manajemen Universitas Dian Nuswantoro. 2012.

http://eprints.dinus.ac.id/15075/1/JURNAL_TESIS_(P32.2009.00137).p df download 5 Januari 2018

[10] Anggraeni. Nia, Marnis, and Samsir, "Strategi Orientasi Pasar, Inovasi dan Orientasi Pembelajaran Pengaruhnya Terhadap Kinerja Usaha serta Dampaknya Terhadap Keunggulan Bersaing (Studi pada Jasa Salon Kecantikan dan Spa di Kota Pekanbaru)," Jurnal Sosial Ekonomi Pembangunan, vol. 4 (12), 2014, pp. 295-310.

[11] Utaminingsih, AdijatiPengaruh Orientasi Pasar, Inovasi, dan Kreativitas Strategi Pemasaran Terhadap Kinerja Pemasaran pada UKM Kerajinan Rotan di Desa Teluk Wetan, Welahan, Jepara. Media Ekonomi dan Manajemen31 (2), 2016, h: 77-87.

[12] Charles. L.C. Joel and Kotut C. Samwel, "Market Orientation and Firm Performance in The Manufacturing Sector in Kenya," European Journal of Business and Management, vol. 4 (10), 2012, pp. 20-27.

[13] Maslucha Nur'aini dan Sanaji. Pengaruh Orientasi Pasar Terhadap Kinerja Pemasaran Melalui Inovasi. Jurnal Ilmu Manajemen, 1 (4), 2013..h: 1-12.

[14] Prakosa, Bagas. Pengaruh OrientasiPasar, Inovasi dan Orientasi Pembelajaran Terhadap Kinerja Perusahaan untuk Mencapai Keunggulan Bersaing (StudiEmpiris Pada Industri Manufakturdi Semarang). Journal Studi Manajemen \& Organisasi, 2 (1), 2005. h: 35 57.

[15] Afsharghasemi. A, Zain. M, Sambasivan. M, and Imam. S.N.S, "Market Orientation, Government Regulations, Competitive Advantage \& Internationalization of SMEs: A study in Malaysia," Journal of Business Administration Research, vol. 2 (2), 2013, pp. 13-22.

[16] Atalay. M, Anafarta. N, and Sarvan. F, "The relationship between innovation and firm performance: An empirical evidence from Turkish automotive supplier industry," Procedia - Social and Behavioral Sciences, vol. 75 (2), 2013, pp. 226-235.

[17] Cahyo. J.K. and Haryanti. D, “Analisa Inovasi Produk Pada Sektor Usaha Formal dan Informasi di Jawa Timur," Jurnal AGORA, vol. 1 (3), 2013, pp. 1-5.

[18] Zaini, Achmad, Hadiwidjojo, D., Rohman, F., and Maskie, G. Effect Of Competitive Advantage As A Mediator Varible Of Entrepreneurship Orientation To Marketing Performance. IOSR Journal of Business and Management (IOSR-JBM), 16 (5), 2014. pp: 05-10.

[19] Halim, Djumilah, H., Solimun dan Djumahir. Kapabilitas Pemasaran sebagai Mediasi Pengaruh Orientasi Pasar, Orientasi Pembelajaran dan Orientasi Kewirausahaan terhadap Kinerja Pemasaran (Studi pada Usaha Menengah di Sulawesi Tenggara). Jurnal Aplikasi Manajemen10 (3), 2012, h: 472-484.

[20] Prasetya, A.Y.. Analisis Faktor yang Mempengaruhi Keunggulan Bersaing Produk dalam Rangka Meningkatkan Kinerja Pemasaran. Jurnal Ilmu Manajemen dan Akuntansi Terapan, 3 (2), 2012. h: 7-17

[21] Riduwan, Kuncoro. Cara Menggunakan dan Memakai Path Analysis (analisis jalur). Bandung: Alfabeta. 2011
[22] Setiawan, Heri. 2015. Pengaruh Orientasi Pasar, Budaya Organisasi, dan Orientasi Kewirausahaan Terhadap Kinerja Usaha (Studi pada Usaha Kecil Pengolahan di Kota Palembang). Jurusan Administrasi Bisnis Politeknik Negeri Sriwijaya, 13 (2), h: 152-165.

[23] Pertiwi, Yunita Dwi. dan Siswoyo, Bambang Banu.. Pengaruh Orientasi Pasar Terhadap Kinerja Pemasaran pada UMKM Kripik Buah di Kota Batu. Syariah Paper Accounting FEB UMS, 3, 2016. h: 231-238.

[24] Alrubaiee. Laith, "An Investigation on the Relationship Between New Service Development, Market orientation, and Marketing Performance," European Journal of Bussiness and Management, vol. 5 (5), 2013, pp. 1 26.

[25] Killa, Maklon Felipus. Effect of Entrepreneurial Innovativeness Orientation, Product Innovation, and Value Co-Creation on Marketing Performance. Journal of Research in Marketing, 2 (3), 2014. pp: 198204.

[26] Rodriguez, A. L. L., and Morant, G. A. Linking Market Orientation, Innovation and Performance: An Empirical Study on Small Industrial Enterprises in Spain. Journal of Small Business Strategy, 26 (1), 2016. pp: $37-50$.

[27] Jhonson, A.J., Dirbell, C.C., and Hansen E.. Market Orientation, Innovativeness, and Performance of Food Companies. Journal of Agribusiness, 27 (1/2), 2009, pp: 85-106 